\title{
LogForum
}

\section{THE NEW SILK ROAD: OPPORTUNITIES FOR GLOBAL SUPPLY CHAINS AND CHALLENGES FOR FURTHER DEVELOPMENT}

\author{
Norbert Wagener ${ }^{1}$, Bernard Aritua ${ }^{2}$, Tong $\mathrm{Zhu}^{2}$ \\ 1) Poznan School of Logistics, Poznań, Poland, 2) The World Bank Group, China
}

\begin{abstract}
Background: Efforts to revive the New Silk Route from Europe to Asia have been on-going since the late 1970s. However, the launch of the Belt and Road Initiative (BRI) of the PR China in 2013 has given new impetus to Europe-Asia connectivity. Between 2014 and 2018 the number of block trains between China and Europe (including Russia) increased from 298 to 4,982 per year. Will this trend continue? Which bottlenecks and challenges appear? What are opportunities for respective countries, policy makers, shippers and logistics operators? The paper contributes to the scientific question of further and sustainable segmentation of intermodal transport markets in the context of global supply chains.

Methods: Based on a literature review and interviews with logistics operators and shippers the authors analyze the present design and operational parameters of the intermodal land bridge traffic system, major challenges and bottlenecks and propose measure how to enable further growth and to improve the sustainability of this traffic.

Results: Main issues of the further development of the New Silk Road Europe China are technological innovations, digitalization of supply chains, optimizing of intermodal transport and gateway concepts, corridor management and new trading patterns with e-commerce.

Conclusions: Although this intermodal land bridge connection will likely continue to be a niche market, it offers considerable transit time and cost savings for specific types of freight where air freight is too expensive and maritime logistics is too slow. At higher freight costs compared with the sea freight and lower fares than air cargo this is especially interesting for high value cargo and the Northern provinces of China; also for opportunities in Central Asia, and the Caucasus. The new transport route promotes not only investments into production sites for export at locations in the Northern provinces but also opens new opportunities for European exports of industrial goods and FMCG for the growing middle class in China. The total logistics costs from the viewpoint of a shipper can be more competitive via land bridge than via sea. Both production and distribution networks of large companies (e.g. BASF, HP, BMW) and small and medium sized companies (here especially through e-commerce) can benefit from a further integration of markets and globalization of supply chains.
\end{abstract}

Key words: New Silk Road, Belt and Road Initiative, Global Supply Chains, Intermodal Transport, Digitalization, Corridor Management.

A part of this study was presented as oral presentation at the „8th International Logistics Scientific Conference WSL FORUM 2019” in Poznan (Poland), 18th-19th of November 2019.

\section{INTRODUCTION}

"Silk Route" is a term describing a network of land based trade routes, formerly with caravans between China and Europe initiated during the Chinese Han Dynasty (207 BC to 220 AD). These trade routes cross China,
Kazakhstan, Kyrgystan, Turkmenistan, Tajikistan, Uzbekistan, Iran, the Caucasus and Turkey. Over time the routes and names changed. Nowadays the "New Silk Route" (also "Iron Silk Route") covers this historical Southern route but also a Central route via Kazakhstan and Russia as well as Northern routes via Mongolia and Russia (Fig. 1). 
A major backbone is the Trans-Siberian Railway whose construction started in 1891 under the Russian Tsar Nikolaus III and connects Moscow with Vladivostock at the Pacific. With $9,289 \mathrm{~km}$ it is the longest railway in the world. At the eve of containerization in the 1970s of the 20th century this route gained importance for rail container transport from Europe (mainly Germany, Switzerland and Finland) to Russia and China. Since the beginning one can recognize steady improvements of operation from inefficient waggon loads, on demand traffic and unpredictable transit times towards more efficient block trains, fixed schedules and very competitive transit times. The growing foreign trade between China and Europe, the industrialization of North China and the increased reliability of intermodal rail connections were the main drivers of this development.

Especially the introduction of time table related train schedules and reliability of service were the very preconditions to integrate this route into supply chains of intercontinental production and distribution networks.

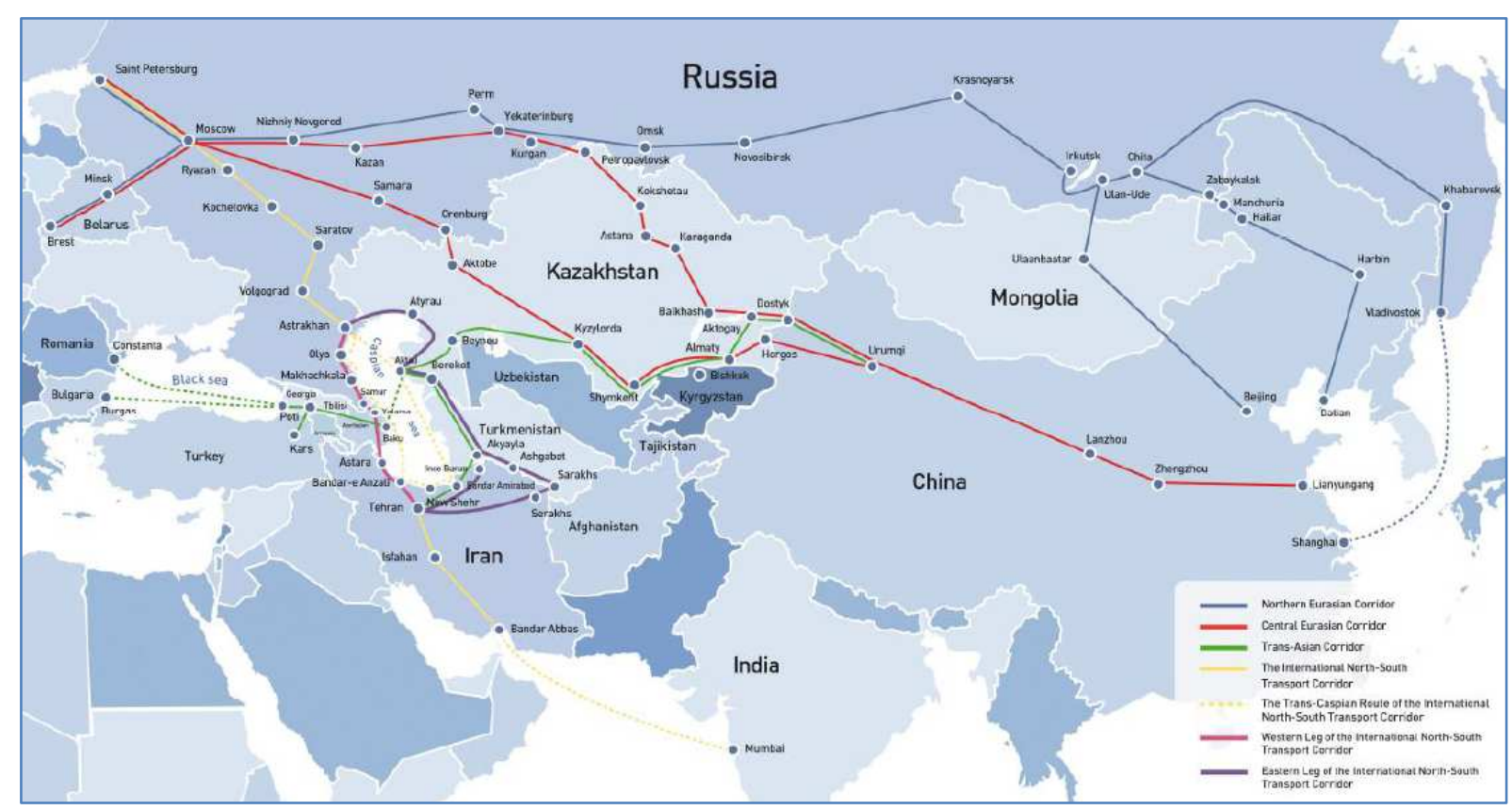

Source: Beifert, et al., 2018

Fig. 1. Eurasian Corridors

\section{DEVELOPMENT OF THE CHINA - EUROPE LANDBRIDGE TRAFFIC}

The "New Silk Route" has experienced a dynamic rise since the start of the BRI of the PR China in 2013. Physical connectivity and trade are prioritized by BRI along with other aspects including policy, finance, and culture. From 2013 to 2018, the total value of goods trade between China and BRI countries exceeded US\$6 trillion. As a consequence, logistics has been impelled. Especially, between 2013 and 2018 the number of block trains between China and Europe (including from / to Russia and Central Asia) increased from 80 to 6,363 per year. As of June 2019, a cumulative number of 17,000 China-Europe block train trips was completed reaching 53 cities in 16 countries via east, middle, and west gateways respectively Manzhouli, Erenhot, and Khorgos [Belt and Road Portal, 2019].

$78 \%$ of all block trains from / to China relate to Europe. The Chinese government's forecast that around 5,000 block trains will travel to Europe in 2020 has already been reached in 2018. With an average capacity of $90 \mathrm{TEU} /$ train, this equates to some 450,000 
Wagener N., Aritua B., Zhu T., 2020. The New Silk Road: Opportunities for Global Supply Chains and Challenges for Further Development. LogForum 16 (2), 193-207. http://doi.org/10.17270/J.LOG.2020.403

TEU in both directions. The unbalance of the traffic could be reduced continuously.

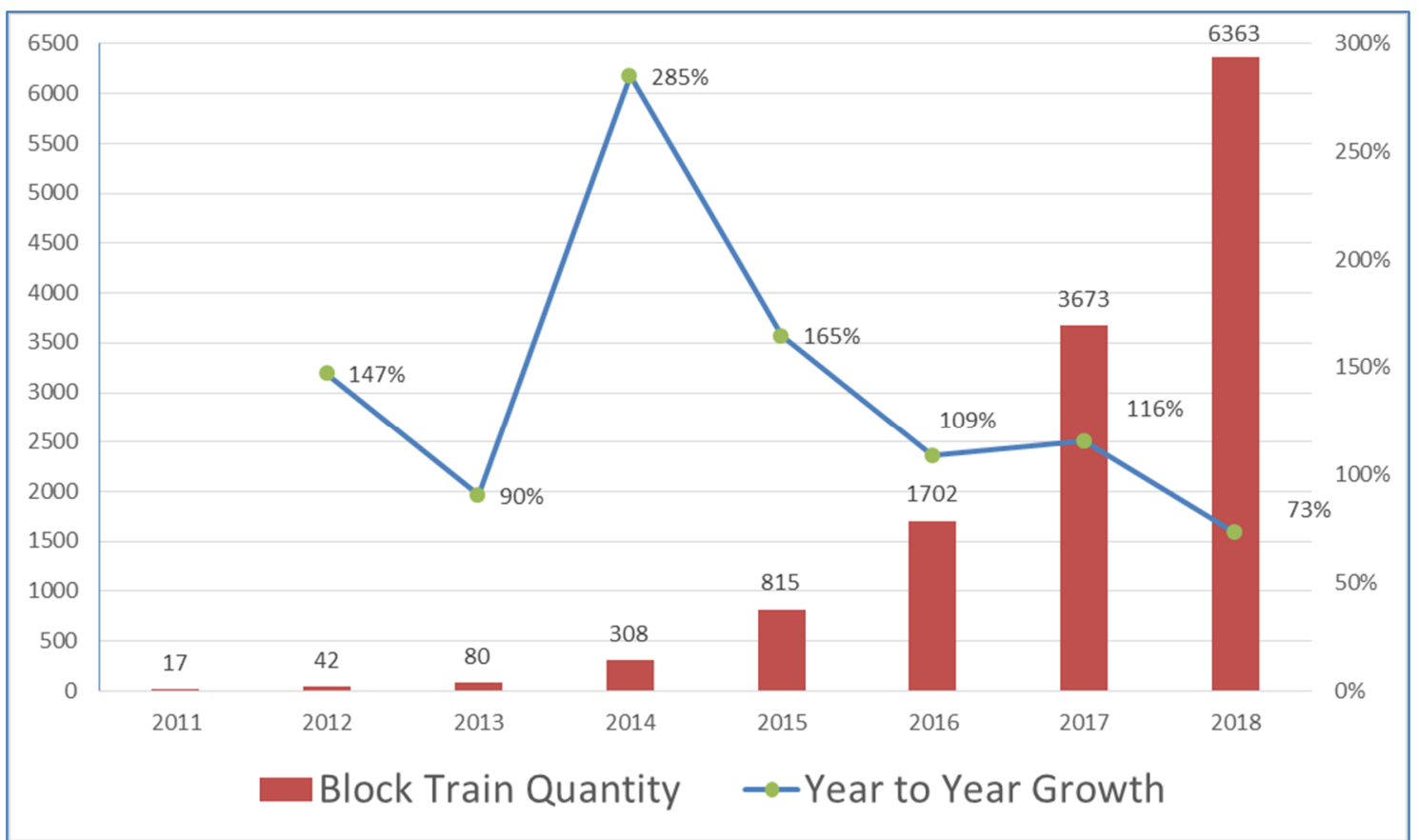

Source: Belt and Road Portal, see https://www.yidaiyilu.gov.cn/ydylcylznzd/cjc/102467.htm

Fig. 2. Number of block trains between China and Europe (including Russia)

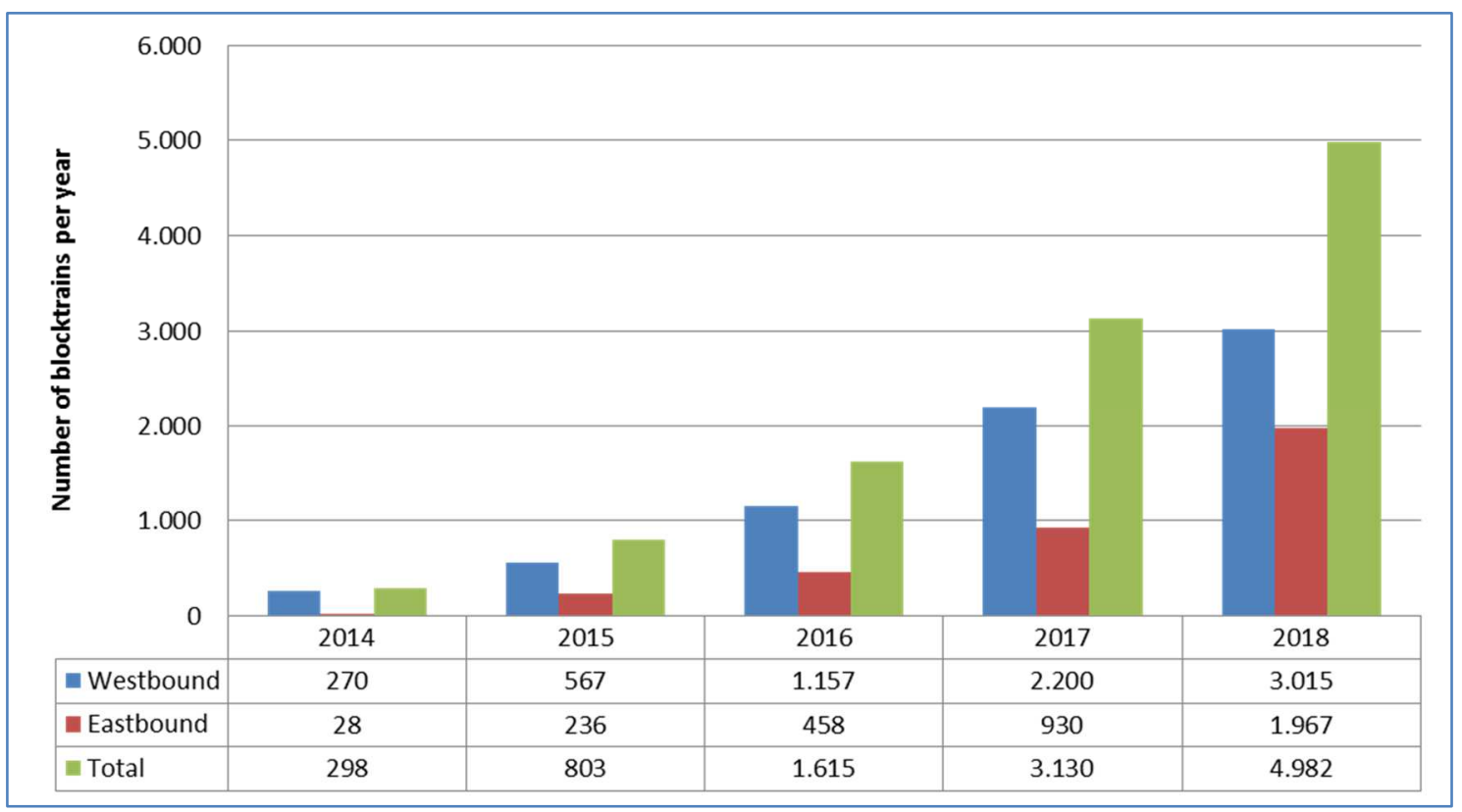

Source: Chinese Railways, https://card.weibo.com/article/m/show/id/2309404326026917355445

Fig. 3. Number of block trains (Eastbound / Westbound) between China and Europe (excluding Russia) 


\section{INTEGRATION OF THE NEW SILK ROUTE INTO GLOBAL SUPPLY CHAINS}

The "New Silk Route" opens new opportunities for global supply chains as well as for the regional development in the northern provinces of China but also for developing regions in transit countries along the corridors. Multinational companies and exporters benefit from the new rail based corridors complementing the established sea and air services between China and Europe. Picture 4 shows that the time / costs - ratio of rail shipments lays between air and sea transport, i.e. half of the time of sea freight for one third of the costs of air freight.
With this specific time / costs ratio the rail services between China and Western Europe serve a special market segment for more time but less costs sensitive commodities than in sea freight, especially to/from Northern China and inland destinations in Western Europe.

According to a recent study it is estimated, if cargo sent by ocean vessel had a value higher than $€ 85,000$ per TEU, it would be more cost-effective to shippers to send it by rail. This study comes to the conclusion, that of the two-way sea freight of forecasted 40 million TEU (including empty containers) in 2040, around 2.5 million TEU could transfer to rail [Steer Davies Gleave, 2018].

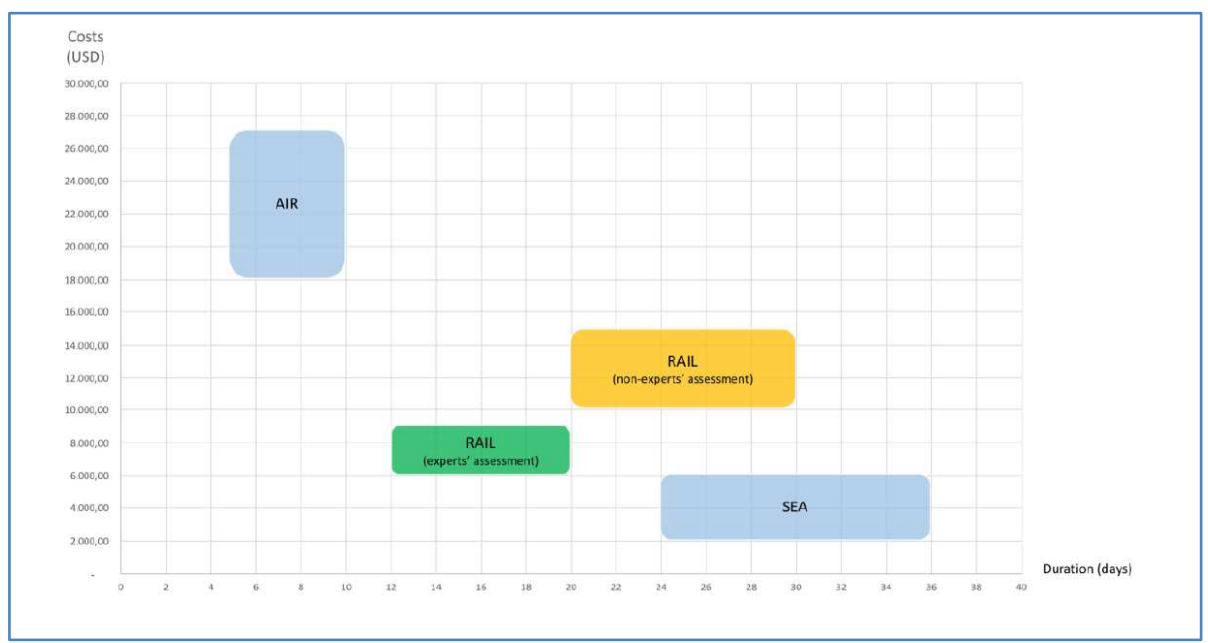

Source: Beifert, et al., 2018

Fig. 4. Estimation of the standard TEU container shipment from China (e.g. Chongqing) to Western Europe (e.g. Duisburg, Germany)

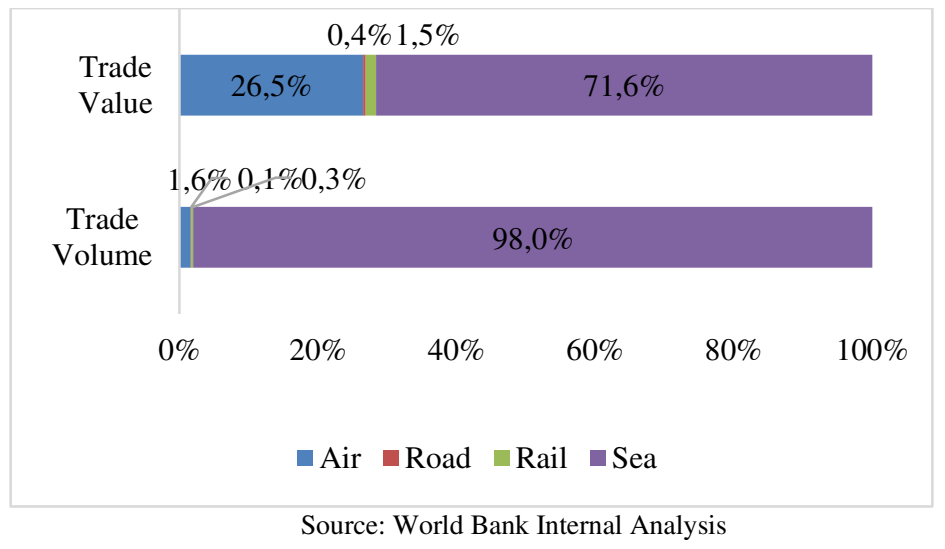

Fig. 5. Composition of China-Europe Freight by Value and Volume by Transport Mode (2016) 
For the foreseeable future, the majority of freight by volume will continue to use maritime routes. However, for the niche markets, the land bridge offers an interesting alternative. As of 2016, about $98 \%$ of EuropeChina freight is moved by maritime transport with aviation and railways accounting for $1.6 \%$ and $0.3 \%$ respectively. Air freight dominates high value goods. Although constituting $1.6 \%$ of total freight volume, air cargo makes up some $27 \%$ of value of freight. The opportunity exists for freight between $€ 6,000$ to $€ 15,000$ per ton to use the rail-based land bridge. The challenge is making this alternative mainstream.

For transit rail freight between Europe and China, further analysis shows that most of freight coming from Europe to China consists of private cars and components as well as of engineering products (engine parts, pumps, electrical components etc.). These manufactured products constituted $50 \%$ of total freight by volume. Other notable products include chemical products and timber by products (paper and pulp). The reverse cargo from China to Europe is made up of machinery, equipment, and industrial products which make up about 55\%. Others include raw minerals and chemical materials, construction materials, clothing, textiles, and footwear. All these major freight categories are niche freight types suitable for containerization that would normally not go by air freight due to the costs of transit but which moving by ship would take longer than most shippers would prefer.

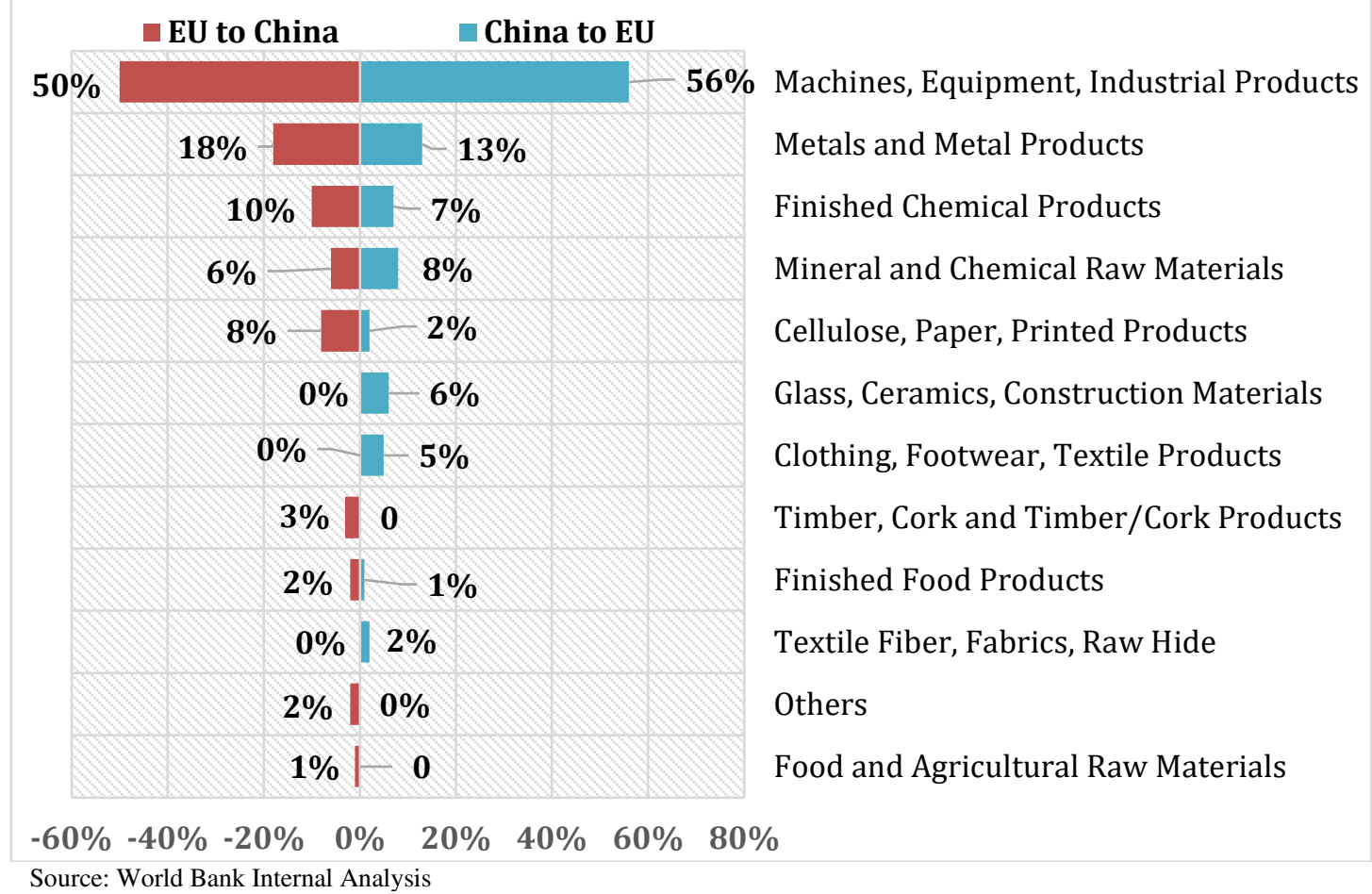

Fig. 6. Commodity Structure of EU Railway-Carried Exports to/Imports from China (2016)

In the current situation, containers remain the preferred method of delivery of freight between Europe and China. The use of containers guarantees preservation of cargo, standard dimensions, reduced packaging costs, accelerated cargo handling, and can facilitate unified shipping documents and forwarding.
Therefore, any discussion of infrastructure and logistics needs for transit freight between Europe and China must take place, primarily, in the context of intermodal freight solutions.

In a globalized economy production sites of large multinational companies or collaboration 
networks move over time as a result of seeking optimum profitability. Also consumption behaviors change with increasing welfare. As a result, international trading patterns may change gradually or even totally in the future. Therefore, predicting future patterns in freight transport is very difficult . Logistics strategists in multinational companies seek to plan their supply chains as cost efficient and as flexible and agile as possible. International transport operators and logistics service providers are in need to offer alternatives and permanent adjustments of their services. In this respect the "New Silk Route" should not be seen as a point to point corridor between Europe and Asia only but as a comprehensive transport network connecting numerous locations in more than 40 countries in Asia and Europe which allows a high degree of flexibility in changing supply chains and distribution to markets.

\section{Example: BMW supply chain Leipzig (Germany) - Shenyang (China)}

An example for changing trade patterns and corresponding adjustments of supply chains is the development of BMW in China. The country is BMW's largest single sales market, with 560,000 vehicles sold there in 2017. BMW plans to invest 3.5 billion $€$ in China, in particular in new and existing plant facilities in Shenyang, increasing production capacity to 650,000 vehicles a year from the early 2020 s.
The plants produced 400,000 vehicles in 2017 . The new plant will produce fully electric, partly electric, and conventional vehicles on the same line [Industrial Equipment News, 2018].

The first BMW container train was launched in 2011 as a private company train. About 8,000 different car components are carried over the $11,000 \mathrm{~km}$ route from Leipzig and Regensburg to China, for assembling in the joint venture company BMW Brilliance in Shenyang. Now the train needs 17 days only (20 days door-to-door) and runs daily on the relation Leipzig - Shenyang. Compared with airfreight the rail transport saves 150,000 tons $\mathrm{CO}_{2}$ per annum. The train is operated by $\mathrm{DB}$ Schenker and is open for third clients also. (Railways, 2016) German car manufacturers send about 63,000 cars CKD (completely knocked down) annually for further assembling in China in order to avoid high import duties. [Handelsblatt, 2019] With the new factory in Shenyang for electric cars the import of components may be expected to rise thus reducing the imbalance of the trade. These dedicated company trains between production sites serve as "warehouses on wheels" within Just-In Time international supply chains. $100 \%$ reliability is a very precondition for production planning systems and sales programs.

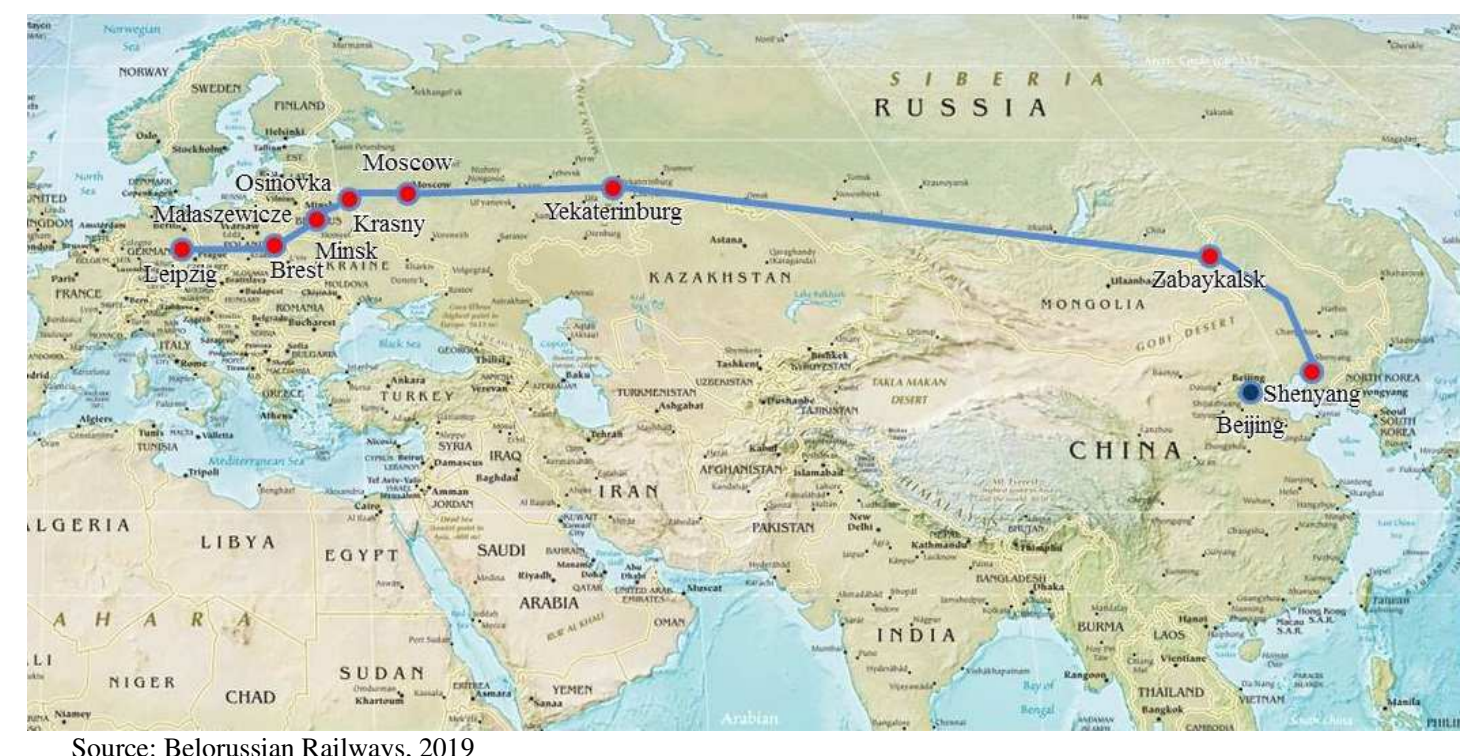

Source: Belorussian Railways, 2019

Fig. 7. Route of the BMW company train between Leipzig and Shenyang via Brest and Zabaikalsk 


\section{OBSTACLES AND CHALLENGES}

The lack of interoperability of railways in terms of legal, operational and technical terms is a major historical obstacle for traffic along the routes. But there are also capacity, economic and financing constraints which need to be tackled.

\section{Lack of systematic design and coordination}

There are over 60 cities operating westbound block trains to Europe. All these routes are managed by local governments. The lack of systematic top-level design and regional coordination has led to inefficiency in terms of railway capacity utilization and resource allocation.

\section{Different technical systems of railways}

Different gauges, electricity systems, train lengths, signaling and rule books are the main technical obstacles. For example on the route from Duisburg (Germany) to Lanzhou (China) depending on the routing $77 \%$ to $95 \%$ is double track and $68 \%$ to $95 \%$ is electrified.

Table 1. Technical parameters of different routes between Duisburg and Lanzhou

\begin{tabular}{|c|c|c|c|}
\hline Sections of the route & $\begin{array}{l}\text { Distance, } \\
\text { km }\end{array}$ & $\begin{array}{l}\text { Double track, } \\
\text { km }\end{array}$ & Electrified, km* \\
\hline \multicolumn{4}{|l|}{ TransSib - Kazakh route } \\
\hline Duisburg - Moscow & 2,363 & 2,363 & 2,363 with $3 \mathrm{kV}$ DC and $25 \mathrm{kV}$ AC $50 \mathrm{~Hz}$ \\
\hline Moscow - Dostyk & 4,353 & 3,514 & 3,514 with $3 \mathrm{kV}$ DC and $25 \mathrm{kV}$ AC $50 \mathrm{~Hz}$ \\
\hline $\begin{array}{l}\text { Dostyk - Lanzhou } \\
\text { Total Duisburg Lanzhou }\end{array}$ & $\begin{array}{l}2,402,3 \\
\mathbf{9 , 1 1 8 , 3}\end{array}$ & $\begin{array}{l}1,676 \\
7,553\end{array}$ & $\begin{array}{l}295 \text { with } 25 \mathrm{kV} \text { AC } 50 \mathrm{~Hz} \\
\mathbf{6 , 1 7 2}\end{array}$ \\
\hline \multicolumn{4}{|l|}{ TransSib - Mongolian route } \\
\hline Duisburg - Moscow & 2,363 & 2,363 & 2,363 with $3 \mathrm{kV} \mathrm{DC}$ and $25 \mathrm{kV}$ AC $50 \mathrm{~Hz}$ \\
\hline Moscow - Zamyn Uud & 7,021 & 5,654 & 5,649 with $3 \mathrm{kV}$ DC and $25 \mathrm{kV} \mathrm{AC} 50 \mathrm{~Hz}$ \\
\hline $\begin{array}{l}\text { Zamyn Uud - Lanzhou } \\
\text { Total Duisburg Lanzhou }\end{array}$ & $\begin{array}{l}2,645 \\
\mathbf{1 2 , 0 2 9}\end{array}$ & $\begin{array}{l}1,781 \\
\mathbf{9 , 7 9 8}\end{array}$ & $\begin{array}{l}1,857 \text { with } 25 \mathrm{kV} \text { AC } 50 \mathrm{~Hz} \\
\mathbf{9 , 8 6 9}\end{array}$ \\
\hline \multicolumn{4}{|l|}{ TransSib - Manchurian route } \\
\hline Duisburg - Moscow & 2,363 & 2,363 & 2,363 with $3 \mathrm{kV}$ and $25 \mathrm{kV} 50 \mathrm{~Hz}$ \\
\hline Moscow - Zabaykalsk & 6,660 & $6,442,4$ & $6,442,4$ with $3 \mathrm{kV}$ and $25 \mathrm{kV} 50 \mathrm{~Hz}$ \\
\hline Zabaykalsk - Lanzhou & 4,033 & 3,579 & 3,042 electrified with $25 \mathrm{kV} 50 \mathrm{~Hz}$ \\
\hline Total Duisburg - Lanzhou & 13,056 & $12,384,4$ & $10,201,2$ \\
\hline
\end{tabular}

Source: European Commission DG TREN, 2012

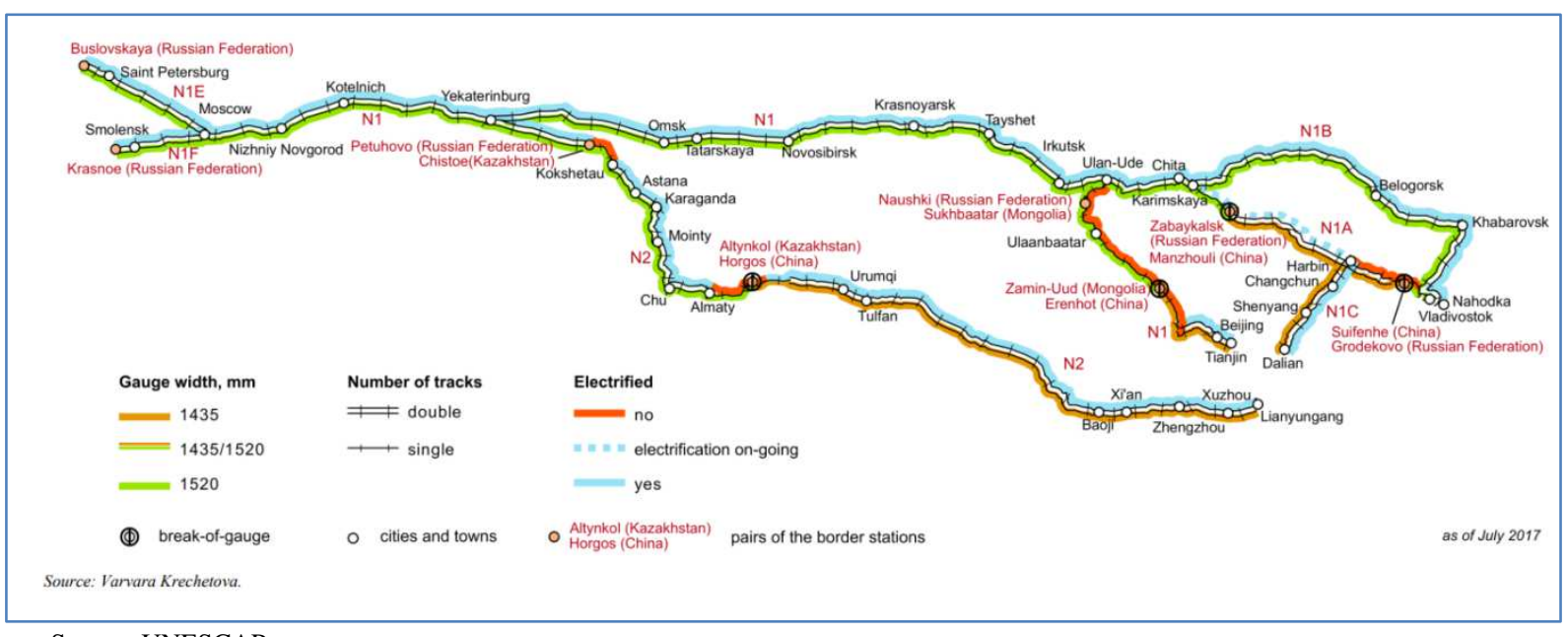

Source: UNESCAP

Fig. 8. Illustration of Existing Rail Routes Connecting Western China to Europe 
For example, the Russian railway lines on the TSR are electrified and double tracked with several of the remaining sections in process of electrification. The main constraint is in Mongolia were the lines are single tracked and in poor condition.

In general, however, since transit trains travel on scheduled services, the railways in Russia and Kazakhstan are more than able to accommodate the containerized services at current volumes. Container transit through Belarus runs through an electrified doubletrack section. Moreover, some $\$ 2.5$ billion were invested in 2011-2017 in projects designed to enhance the Belarusian Railways' capacity, including a $\$ 700$ million investment in the development of Belt and Road routes. To deal with the congestion on the European railway network, some shippers have set up distribution centers to complete the final leg by truck. This is likely a short-term solution. In the long run, on-going investments in Polish railways and the rest of the EU rail network will alleviate the capacity constraints on the networks. However, it is likely that in the medium term this will affect the level of service and cap the potential growth in throughput [Bernard Aritua, 2019].

Quality and capacity of crossing point between Brest in Belarus and Małaszewicze in Poland

Most trains on the Northern routes access Europe through the Belarus-Poland link. The importance of Belarus has been magnified by the breakdown of political relations between Russia and Ukraine - which would otherwise serve as a secondary entry point to Europe. Before the transit freight between Europe and China increased dramatically in 2016 an average of 5 trains per day crossed the border from Belarus to Poland at the BelarusMałaszewicze crossing. By the end of 2017 the number of trains exceeded 10 per day. This has proved to be more than the crossing can efficiently handle. Due to change in railway gauge, all freight needs to be transshipped and because the railway infrastructure, locomotive fleet, and rolling stock have not been upgraded for a long time, this crossing is an impediment to free flow traffic. As traffic has increased, this has placed considerable strain on the transshipment facilities. The response by operators has been to look for alternative endpoints in Europe, such as Lithuania, Finland and Kaliningrad until capacity at the main crossings is increased.

\section{Train length restrictions}

The length of trains composed by various railway companies depends on a number of factors: length of station tracks, train weight, locomotive power, route profile, technical capabilities of route legs (crossing points/stations, side tracks, passing tracks and way stations, whether automatic block systems are employed, intermediate light signals), station track plans and profiles, shunting work conditions at individual stations, technical and technological capabilities of intermediate and line stations, marshalling yards, etc. The length of the train determines the load - in this case, the number of containers loaded onto container platforms. Typically, most trains from China bound for Europe are $801 \mathrm{~m}$ long. This is not a problem until the trains get to Poland which according to applicable norms and regulations cannot accommodate trains exceeding $600 \mathrm{~m}$. Therefore, as part of the transshipment the train-lengths must be reduced while the remaining containers wait at the marshalling yard for the next train [Aritua, 2019].

\section{Railway Track Gauge changes}

The difference in railway track gauges between former USSR countries $(1,520 \mathrm{~mm})$, the PRC $(1,435 \mathrm{~mm})$, and Western Europe $(1,435 \mathrm{~mm})$ requires the transshipment of cargoes or exchange of bogies at border crossing stations. Three main options exist to increase interoperability: (a) transshipment from rolling stock running on 1,435/1,520 mm gauge to rolling stock running on 1,520/1,435 mm gauge; (b) use of variable gauge rolling stock, enabling seamless transition from one gauge to another; (c) bogie exchange at an interchange station. At present, the least cost option is transshipment but this relies on the capacity of siding tracks and gantries [Aritua, 2019]. A China-Europe block train goes through two transshipments on average before reaching a final destination, adding $50 \%$ of operational cost [Jiaoe, 2018]. 


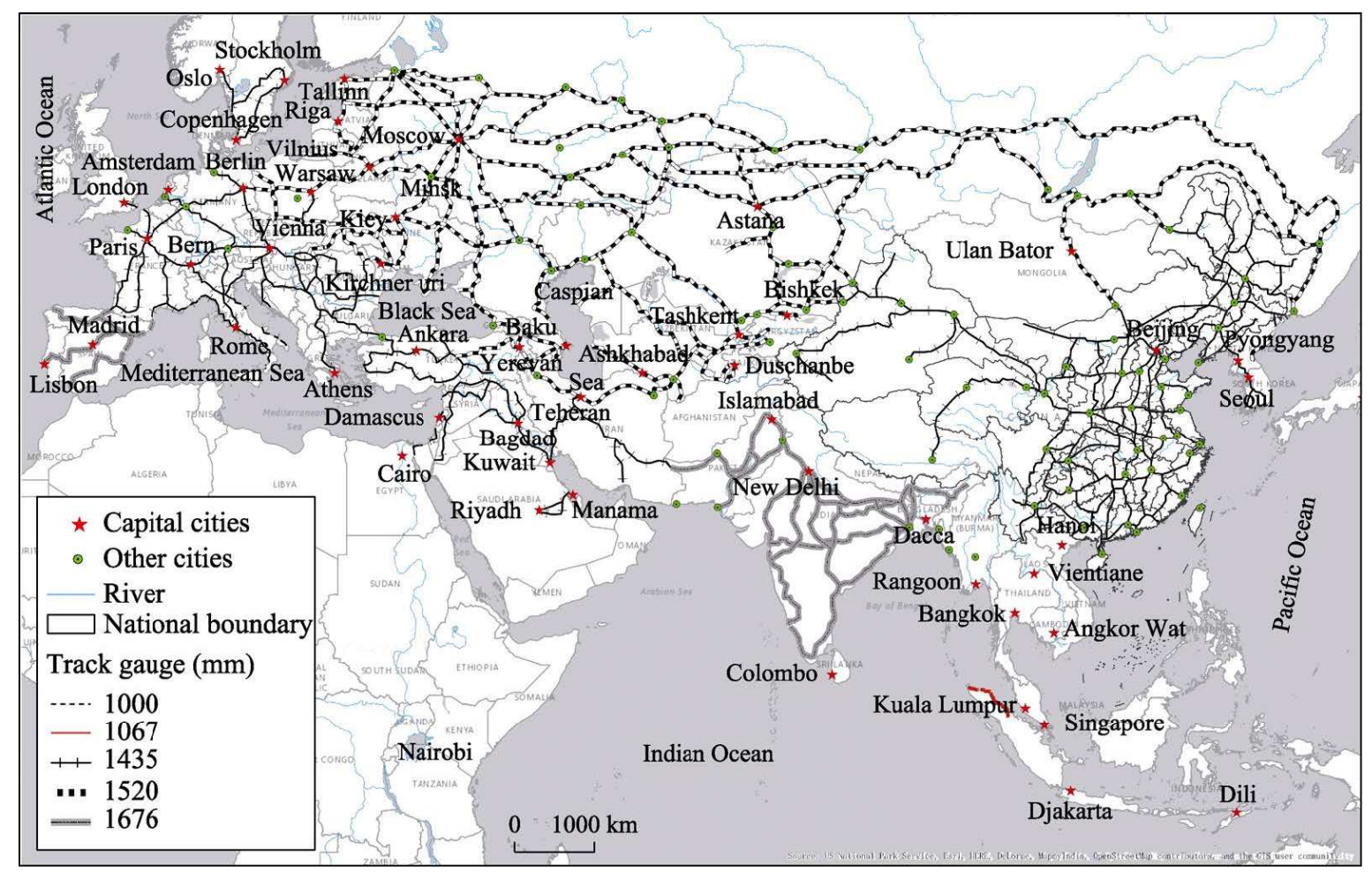

Source: Jiaoe, 2018

Fig. 9. Rail Track Gauges in BRI Countries

\section{Administrative \& legal obstacles}

There are some challenges related to border and customs formalities, however, feedback from forwarders and logistics companies report that these do not currently represent a serious barrier for transit rail freight and trade. Most countries in the region have started pursuing a coherent policy designed to standardize rules and documents to minimize the time required to complete formalities. These efforts are codified in agreements within the Eurasian Economic Union and Trans-Asian railway agreements.

Insufficient standardization of shipping documents and technical regulations remains the main administrative and legal obstacle to the increase of freight along the whole route. Railway freight traffic is regulated in EU countries by the Convention concerning International Carriage by Rail (COTIF). CIS countries, the Baltic States, Albania, Iran, the PRC, the DPRK, Vietnam, Mongolia,
Hungary, and Slovakia use the Agreement on International Goods Transport by Rail (SMGS). The use of the CIM/SMGS common consignment note gives a strong competitive edge to railway shipments through Eurasian space. However, more work needs to be done to standardize normative documents and technical regulations used in Eurasian countries (rules for shipping various types of cargoes, rolling stock operating parameters, environmental standards, etc.). For Eurasian railway services, implementation of the CIM/SMGS common consignment note in electronic form is assessed to be the biggest potential source of bottleneck alleviation that would reduce delays and economic losses. [UNESCAP, 2017] Legal and regulatory systems are being harmonized for the transit freight through the Eurasian Economic Union, yet additional coordination between the Eurasian Economic Union and China would be advantageous. 


\section{Economic \& financing challenges}

In order to promote regional development and to meet freight volume targets Chinese province governments subsidize block train costs. Subsidies range from under $50 \%$ to about $75 \%$ of the unsubsidized costs [World Bank Group, 2019]. The Chinese government is going to reduce these subsidies continuously which challenges transport operators and their customers to find new solutions to make block trains more economical. The growing traffic and the need for more efficient operation require big infrastructure investment and rail rehabilitation projects which go beyond the financial possibilities of investors or governments, especially of smaller countries. Also megaprojects bear high risks which need to be controlled.

Table 2. China-Europe Block Train Subsidy by province in China (2018)

\begin{tabular}{|l|c|}
\hline \multicolumn{1}{|c|}{ City } & Subsidy to China-Europe Block Train \\
\hline $\begin{array}{l}\text { Harbin, Xi'an, } \\
\text { Hefei }\end{array}$ & $\begin{array}{c}\text { US } \$ 3000 \text { per Forty-foot Equivalent Unit } \\
\text { (FEU) }\end{array}$ \\
\hline $\begin{array}{l}\text { Chengdu, } \\
\text { Chongqing, } \\
\text { Guangzhou }\end{array}$ & US\$7,300-7,500 per FEU \\
\hline Suzhou & Corporate income tax refund \\
\hline $\begin{array}{l}\text { Chongqing } \\
\text { Linistry of Finance of China set a subsidy of US\$0.8 per } \\
\text { refund }\end{array}$ \\
\begin{tabular}{l} 
FEU per km as the national guideline \\
\hline
\end{tabular} \\
$\begin{array}{l}\text { Source: China Ports and Harbours Association, 2019, China } \\
\text { Business Journal, 2019 }\end{array}$
\end{tabular}

\section{OPPORTUNITIES FOR THE FUTURE}

How could the traffic become more efficient and profitable in order to compensate subsidies?

\section{Gateway concepts and high performance terminals}

Gateway concepts for container trains would reduce costs further (like airline hubs) through bundling of cargo flows on the main route. Also the last mile transport per road could be reduced. Nowadays trains go to Hamburg and Duisburg and then the oncarriage into the opposite direction backwards to Berlin etc. is on road. More Eastern gateways (e.g. in Małaszewicze (PL) or in Schwarzheide (D) could serve as consolidation
/ bundling hubs connected by train connections further on. More cargo could be attracted, train frequency could be increased, more stations could be connected and finally costs could be reduced.

Małaszewicze (Poland) is a well- suited location for such a gateway function since there is a change of track width between 1,520 $\mathrm{mm} / 1,435 \mathrm{~mm}$. Also the different maximum train lengths of up to $955 \mathrm{~m}$ in Belarus and of $600 \mathrm{~m}$ in Poland require the marshalling of waggons and consolidation of new segmented resp. consolidated trains to Europe resp. to Belarus. Under the provision of adequate infrastructure capacities a future gateway concept in Małaszewicze could serve as a high performance mega hub connecting high capacity and high frequency block trains from Asia with lower capacity and high frequency trains further on to several different locations in Europe and respectively vice versa. Such a mega hub could serve several incoming and outgoing trains by direct transshipment of containers between trains without marshalling of waggons.

Also industry related gateway concepts are feasible. BASF is planning such a gateway for Asian traffic in Schwarzheide in the Eastern part of Germany.

Trains from Western, Northern and Southern Europe will be directed to Schwarzheide where containers are transshipped to trains serving different locations in Eastern Europe and Asia. This enables a higher efficiency and frequency of services.

Significant impulses for Schwarzheide as a gateway are provided by developments in the Chinese market. At present, rail transport of dangerous goods on container trains in China is not yet possible, as regulations prevent this. According to industry insiders, the opening for the transport of dangerous goods is expected. In addition, BASF continues to invest in China and expand the network of production sites. In Guandong, the BASF Group is planning a production site with an estimated investment of approximately $\$ 10$ billion. Completion is scheduled for 2030 [Hofmann, 2018]. 


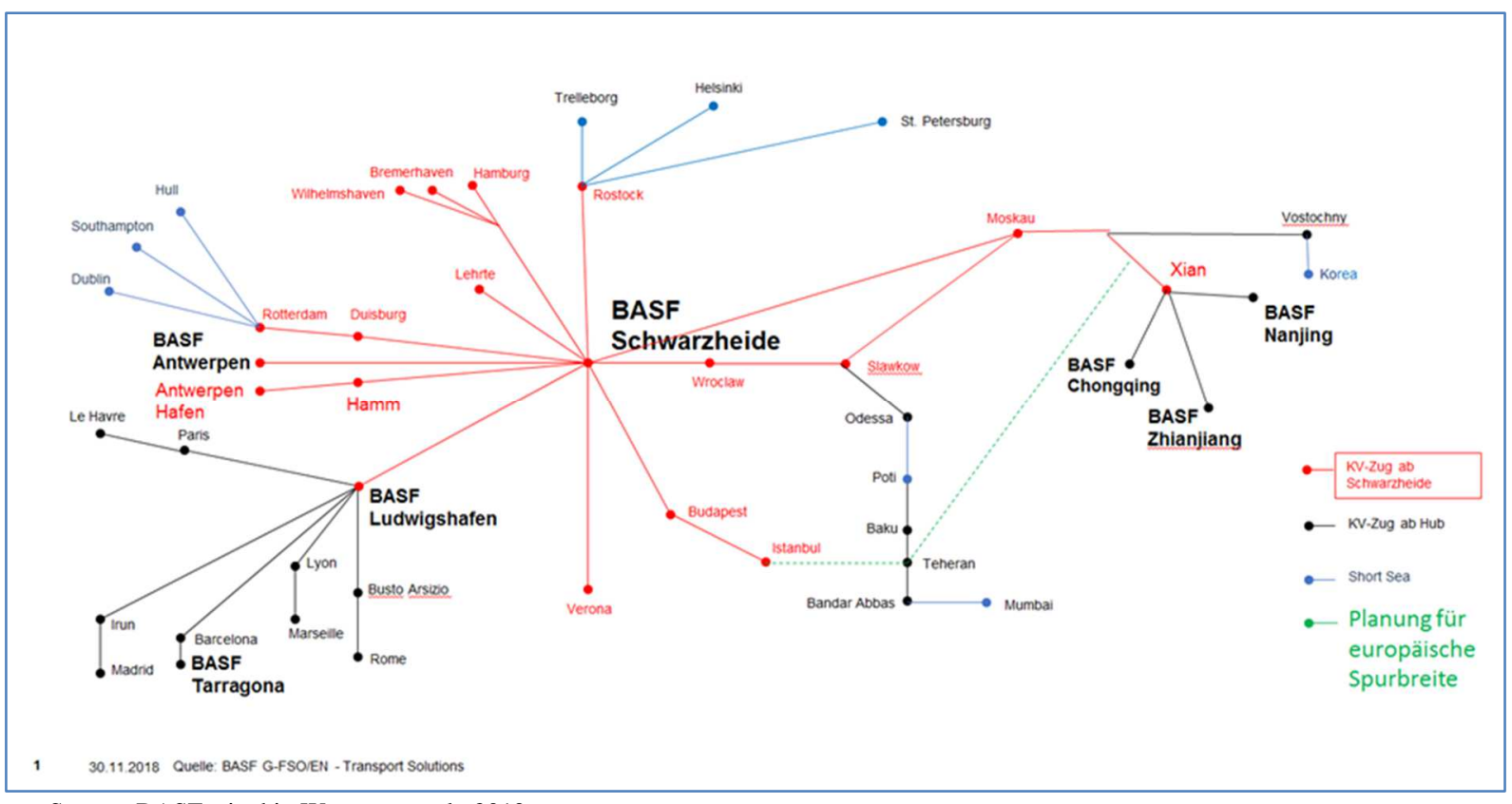

Source: BASF, cited in Wagener, et al., 2019

Fig. 10. Intermodal terminal Schwarzheide (Germany) as a future gateway to Eastern Europe / Asia in the BASF production network

\section{Corridor management}

Especially on the Trans-Caspian route the service is too expensive and not reliable. A better co-operation of countries and railways and a corridor management would be of benefit. On the $1520 \mathrm{~mm}$ countries (Russia, Kazakhstan, White Russia) the company "The United Transport and Logistics Company Eurasian Rail Alliance" (JSC UTLC ERA) as a joint venture of the Kazakh, the Russian and the White Russian railways operates as a joint operator of block trains running through their territories. Also in the European Union rail freight corridors are defined and managed jointly by the European rail infrastructure providers.

Reduction of empty returns from Europe through more balanced trade

In 2018 the Eastbound trade was 1/3 less than the Westbound trade, this results in higher rail freight per container and costs for returning empty containers. A solution is to attract more FMC (Fast Moving Consumer Goods) Eastbound through e-commerce platforms and consolidation / containerization of express cargo in Germany, also for SME export.

\section{Increasing capacity of containers}

Nowadays maritime ISO containers prevail, but in land transport the 45' pallet wide high cube container could offer a larger capacity. 40 ' standard container can carry 22 pallets (1 layer), 45' pallet wide can carry 26 Euro pallets $(80 \times 120 \mathrm{~cm})$. This would increase the capacity by almost $20 \%$.

Expanding the markets for landbridge container traffic

More volume on the landbridge routes could be generated through nodes on the routes connected by antenna routes which serve as feeder connections to middle size agglomerations, like a "fishbone". Also to open the rail market for dangerous goods on Chinese side would boost the demand considerably. This higher traffic volume would result in lower costs through economy of scale.

\section{Digitalization and Blockchain}


Information technology has already improved the operation on the landbridge routes considerably. Containers can be equipped with sensors and real time information via GIS can be provided to the shippers on the actual GPS position of the container, temperature, intrusion and shocks. Operators integrate information from railways on platforms for their clients. Beyond this blockchain technology is an opportunity for the near future to enable full data interoperability, i.e. full paperless information between all parties involved, instant financing and fully door-to-door-tracked container movement in a trusted and secure manner. New technologies such as blockchain have the potential to take over supply chain management and disrupt traditional ways of working. A Proof of Concept (PoC) for Samsung seafreight between Korea and Rotterdam demonstrated that a comprehensive supply chain management system with paperless integration of physical, administrative and financial flows is now feasible [TransFollow, 2019].

Global supply chain involves participants such as manufactures, forwarders, shippers, customs agents, and insurers. Blockchain technology has been proofed as a transparent and immutable shared record book to track containers. Each participant in a global supply chain is able to monitor the status of goods movement with corresponding permissions. Information is shared across the consensus network with high level of security and durability. No party can modify, delete or append any record unilaterally. Blockchain with its featured smart contract framework provides solutions to improve logistics efficiency through the following key features:

- Greater transparency of the logistics process.

- Less paper work and clear responsibility. A pre-defined smart insurance contract is stored on a blockchain and is executed automatically as part of a transaction.

- Trust and credibility grow as all transactions are immutably recorded.

- Costs are reduced by eliminating intermediators.

- Optimize business processes by analysing information chains recorded by blockchain.

\section{POLICY AND FINANCIAL IMPLICATIONS AND RECOMMENDATIONS}

1. It is important for countries along the new Silk Road to harmonize trade and investment policies which are often restrictive, and trade agreements between corridor economies tend to be shallow and fragmented. Gaps in infrastructure compound gaps in policy, and crossregional integration is mostly missing. Border delays can be over 40 times higher in low-performing countries than in the best performing countries.

2. Integrated and synchronized development of infrastructure - particularly for countries in Central Asia will derive more benefit than if countries build railways or roads in isolation. Cross-border cooperation can further enhance the value of a country's investments - by adopting harmonized standards for infrastructure.

3. The value of individual railway projects depends on the realization of others. Project selection and appraisal and the inclusion of BRI projects in national development strategies are essential to avoid stranded infrastructure. Cooperation among participating countries can also ensure that projects are not redundant and that they maximize value from a regional perspective.

4. Some policy reforms to facilitate trade and improve corridor performance require country-specific actions and cooperation. Supply-chain bottlenecks in a single country could block the potential benefit of the entire corridor in unlocking new trade opportunities. Deepening trade agreements among corridor economies could reduce the current fragmentation and establish the rules and mechanisms for trade and other policy reforms.

5. Some Financing Issues- several risks and challenges have to be managed to ensure the benefits are also passed onto transit countries. This includes coordinating infrastructure investments on critical links that cross borders, managing social, environmental, and corruption related risks; and managing public debts. A range of policy and financing instruments will be needed to derisk and to deliver key 
infrastructure while addressing soft issues related to non-tariff barriers (World Bank Group, 2019). International finance institutions can initiate and safeguard investments and institutional mechanisms to support cross-border programs (Beifert, et al., 2018).

\section{CONCLUSIONS}

The New Silk Route between Europe and Asia has proven its importance for an effective functioning of synchronized global supply chains. After a dynamic rise of the intermodal traffic on this New Silk Road since 2013 the route now reaches limits for further growth. Major challenges for further growth are limitations in capacities due to infrastructure bottlenecks, lack of interoperability of railways and of sustainable efficiency (subsidies). As major instruments for further improvements on the New Silk Road country specific actions into infrastructure and international cooperation for a joint corridor development and management could be identified. Also on the operating level co-operation is needed to develop joint train platforms on main routes which are connected via hubs with spoke connections into different regions on both ends of the route in Asia and Europe, complemented by real time information platforms and block chain solutions for trade and transport data.

\section{ACKNOWLEDGMENTS AND FUNDING SOURCE DECLARATION}

Statutory fund of Poznan School of Logistics.

\section{REFERENCES}

Aritua B.N.H., 2019. World Bank Policy Research Working Paper Series: The Belt and Road Initiative Connectivity and Infrastructure Gaps, Beijing: s.n.

Beifert A., Sherbanin Y., Vinokurov E., 2018. Challenges and Opportunities of Economic Integration within a Wider European and Eurasian Space - Trans-Eurasian Land Transport Corridors: Assessment of
Prospects and Barriers, Laxenburg (Austria): IIASA International Institute for Applied Systems Analysis.

Belorussian Railways, 2019. Press Centre BMW. [Online] Available at: https://www.rw.by/cargo_transportation/co ntainer_transportation/accelerated_trains/b mw/ [Accessed 2508 2019].

Belt and Road Portal, 2019. Six Years' Review of Belt and Road Initiative. [Online] Available at:

www.yidaiyilu.gov.cn/xwzx/gnxw/102792. $\underline{\mathrm{htm}}$

China Business Journal, 2019. [Online] Available at: http://www.wuliujia2018.com/html/37743.h tml [Accessed 2709 2019].

China Ports and Harbours Association, 2019. [Online] Available at: http://www.port.org.cn/info/2019/203356.ht $\underline{\text { m }}$ [Accessed 2709 2019].

European Commission DG TREN, 2012. RETRACK WP 13: Potential for Eurasia land bridge corridors \& logistics developments along the corridors, Brussels: European Commission.

Handelsblatt, 2019. Neue Seidenstraße - Wie Österreichs Bahn die europäische Konkurrenz im China-Geschäft abhängen will. [Online] Available at: https://www.handelsblatt.com/unternehmen /handel-konsumgueter/neue-seidenstrassewie-oesterreichs-bahn-die-europaeischekonkurrenz-im-china-geschaeft-abhaengenwill/21229642.html [Accessed 2508 2019].

Hofmann S., 2018. BASF plant 10-MilliardenProjekt in China. Handelsblatt, Issue 09.07.2018.

Industrial Equipment News, 2018. BMW Ramps Up Investment in China. [Online] Available at: https://www.ien.com/supplychain/news/21026860/bmw-ramps-upinvestment-in-china [Accessed 258 2019].

Jiaoe W., 2018. An organizational model and border port hinterlands for the ChinaEurope Railway Express. Journal of Geographical Sciences, 28(9), 1279.

Railways, 2016. Sibirische Zugroute wird zum Erfolgsmodell. [Online] Available at: 
https://www.dbcargo.com/resource/blob/17 96314/544f6a52a136911bc1a0b148b866c7 14/BMW-data.pdf [Accessed 3008 2019].

Steer Davies Gleave, 2018. Research for TRAN Committee: The new Silk route opportunities and challenges for EU transport, Brussels: European Parliament, Policy Department for Structural and Cohesian Policies.

TransFollow, 2019. First blockchain container shipped to Rotterdam. [Online] Available at: https://transfollow.org/news/blockchaindeliver/ [Accessed 3008 2019].

UNESCAP, 2017. Comprehensive Planning of Eurasian Transport Corridors to Strenghen the Intra- and Inter-Regional Transport Connectivity, s.1.: UNESCAP.

Wagener N., Bamler N., Behrens R., 2019. Potenzialstudie für den intermodalen Güterverkehr in der Wirtschaftsregion Lausitz, Bad Muskau: ZukunftsWerkstatt Lausitz.

World Bank Group, 2019. Belt And Road Economics - Opportunities and risks of transport corridors, Washington: International Bank for Reconstruction and Development / The World Bank.

\title{
NOWY JEDWABNY SZLAK: MOŻLIWOŚCI GLOBALNEGO ŁAŃCUCHA DOSTAW I WYZWANIA DLA DALSZEGO ROZWOJU
}

STRESZCZENIE. Wstęp: Próby stworzenia Nowego Jedwabnego Szlaku z Europy do Azji są podejmowane praktycznie bez przerwy od lat 70-tych XX wieku. Jednak dopiero utworzenie inicjatywy Belt and Road Initiative (BRI) przez Chiny w 2013 zdynamizowały stworzenie połączenia między Europą a Azją. W okresie 2014 do 2018 ilość transportów szynowych pomiędzy Chinami a Europa (włączając Rosję) wzrosła z 298 do 4982 rocznie. Czy trend ten będzie utrzymany? Jakie są ograniczenia i wyzwania? Jakie są możliwości dla współudziałowców (krajów), twórców polityki, przewoźników i operatorów logistycznych? Praca ta jest naukowym pytaniem dotyczącym dalszej segmentacji transportu intermodalnego w kontekście globalnych łańcuchów dostaw.

Metody: W oparciu o przegląd literatury naukowej oraz wywiadów przeprowadzonych z operatorami logistycznymi i przewoźnikami, przeanalizowano projektowe i operacyjne parametry system intermodalnych transportów, główne wyzwania i ograniczenia oraz zaproponowano środki umożliwiające przyszłościowy wzrost i zrównoważony rozwój tego typu transportu.

Wyniki: Głównymi czynnikami umożliwiającymi dalszy rozwój Nowego Jedwabnego Szlaku Europa Chiny są nowacje technologicznego, cyfryzacja łańcuchów dostaw, optymalizacja transportu intermodalnego i koncepcji bram, zarządzanie korytarzami oraz nowe metody handlu oparte o e-handel.

\begin{abstract}
Wnioski: Jakkolwiek intermodalne połączenia lądowe pozostaną na razie zapewne rynkiem niszowym, to oferują one istotna oszczędność czasu tranzytu oraz ponoszonych kosztów w przypadku specyficznych typów ładunków, dla których fracht lotniczy jest zbyt drogi a morski zbyt wolny. Szczególnie północne prowincje Chin są zainteresowane tym typem transportu o aczkolwiek wyższych kosztach w stosunku do transportu morskiego ale niższych niż w przypadku transportu lotniczego. Jest to również wielka możliwość dla Centralnej Azji i Kaukazu. Nowe szlaki transportowe promują inwestycje nie tylko w obszary produkcyjne eksportowe dla lokalizacji w północnych prowincjach ale także otwierają nowe możliwości dla eksporterów europejskich dóbr przemysłowych oraz FMCG skierowanych do konsumentów z rosnącej klasy średniej w Chinach. Całkowite koszty logistyczne z punktu widzenia wysyłającego mogą być bardziej konkurencyjne w przypadku trasy lądowej aniżeli trasy morskiej. Duże korporacje zarówno produkcyjne jak i dystrybucyjne (np. BASF, HP, BMW) jak również firmy małej i średniej wielkości (szczególnie korzystające z możliwości e-handlu) mogą wiele zyskać na dalszej integracji rynków oraz globalizacji łańcuchów dostaw.
\end{abstract}

Słowa kluczowe: Nowy Szlak Jedwabny, Belt and Road Initiative, globalne łańcuchy dostaw, transport intermodalny, cyfryzacja, zarządzanie korytarzem 
Norbert Wagener

Poznan School of Logistics, Poznan, Poland

e-mail: norbert.wagener@wsl.com.pl

Bernard Aritua

Senior Infrastructure \& Logistics Specialist - Central Asia, China and Mongolia The World Bank Group, China

e-mail: baritua@worldbank.org

Tong Zhu

Transport Analyst

The World Bank Group, Bejing China

e-mail: tzhu1@worldbank.org 